specialty group, such as family practitioners, wants to learn about one topic, such as psychotropic prescribing practices, is unknown. Increasing our knowledge about physician's educational preferences will improve our ability to develop more evidence-based methods for educating physicians on many other topics, such as the prevention and control of antimicrobial resistance.

Reaching the medical care providers with up-to-date information requires more than a compendium of data and an effective educational method. Understanding the recipient's preferences for type of, and accessibility to, educational media should enhance the impact of these efforts. Medical education should be developed using media that are accessible to and preferred by physicians.

\section{REFERENCES}

1. Birchette KP. The history of medical libraries from $2000 \mathrm{BC}$ to $1900 \mathrm{AD}$. MLA 1973;61:302-308.

2. Goldberg A. Towards European medicine: an historical perspective. $J R$ Coll Physicians Lond 1989;23:277-286.

3. Ell SR. Five hundred years of specialty certification and compulsory continuing medical education. Venice 1300-1801. IAMA 1984;251:752-753.

4. The Royal College of Physicians of London. Ann Intern Med 1968;68: 704-706

5. Davis DA, Thomson MA, Oxman AD, Haynes RB. Evidence for the effectiveness of CME. JAMA 1992;268:1111-1117.

6. Davis DA, Thomson MA, Oxman $\mathrm{AD}$, Haynes $\mathrm{RB}$. Changing physician performance. A systematic review of the effect of continuing medical education strategies. JAMA 1995;274:700-705.

7. Davis D. Does CME work? An analysis of the effect of educational activities on physician performance or health care outcomes. Int J Psychiatry
Med 1998;28:21-39.

8. Oxman AD, Thomson MA, Davis DA, Haynes RB. No magic bullets: a systematic review of 102 trials of interventions to improve professional practice. Can Med Assoc J 1995;153:1423-1431.

9. Bashook PG, Parboosingh J. Continuing medical education: recertification and the maintenance of competence. $B M J 1998 ; 316: 545-548$.

10. Haynes RB, Davis DA, McKibbon A, Tugwell P. A critical appraisal of the efficacy of continuing medical education. JAMA 1984;251:61-64.

11. Gifford DR, Mittman BS, Fink A, Lanto AB, Lee ML, Vickrey BG. Can a specialty society educate its members to think differently about clinical decisions? Results of a randomized trial. I Gen Intern Med 1996;11:664-672.

12. Blumenfeld A, Abraham RB, Stein M, Shapira SC, Reiner A, Reiser B, et al. Cognitive knowledge decline after advanced trauma life support courses. J Trauma 1998;44:513-516.

13. Manning PR, Denson TA. How cardiologists learn about echocardiography. Ann Intern Med 1979;91:469-471.

14. Buchanan $\mathrm{K}$, Laxdal OE. Continuing education habits of Saskatchewan general practitioners. Can Med Assoc J 1971;105:1328-1333.

15. Vetto IT, Richert-Boe K, Desler M, DuFrain L, Hagen H. Tumor board formats: 'fascinating case' versus 'working conference.' J Cancer Educ $1996 ; 11: 84-88$

16. Tinsley JA, Shadid GE, Li H, Offord KP, Agerter DC. A survey of family physicians and psychiatrists. Psychotropic prescribing practices and educational needs. Gen Hosp Psychiatry 1998;20:360-367.

17. Murray-Lyon N. Communication in medicine: a study of how family doctors obtain information on recent advances in the treatment of rheumat ic diseases. Med Educ 1977;11:95-102.

18. Lefkarites BJ, McGann ME, Yeager $\mathrm{KK}$. Continuing education needs assessment: a brief report. Am J Prev Med 1995;11:45-47.

19. Curry L, Putnam RW. Continuing medical education in Maritime Canada: the methods physicians use, would prefer and find most effective. Can Med Assoc J 1981;124:563-566.

20. Berman SJ, Perkocha VA, Novotny TE. A continuing education preference survey of public health graduates. Am J Prev Med 1995;11:19-25.

21. Stinson ER, Mueller DA. Survey of health professionals' information habits and needs conducted through personal interviews. JAMA 1980;243:140-143.

\title{
Condoms as Probe Covers for Transvaginal Sonography
}

\section{Gina Pugliese, RN, MS Martin S. Favero, PhD}

Amis and coinvestigators, from the University Department of Obstetrics and Gynaecology, Royal Free Hospital, London, conducted a prospective study to assess the incidence of transvaginal probe contamination and breakage of condoms used to cover those probes during transvaginal sonography. Over a 9-month period, 214 women underwent transvaginal sonography with probes that had been coated with gel and then covered with a latex condom. Condom defects were detected after the scans by inspection, after adding hydrogen peroxide or filling the condoms with $500 \mathrm{~mL}$ of water. After the condoms were removed, the probe was either wiped with a dry tissue (during the first 18 weeks of the study) or wiped first with a dry tissue and then with a $70 \%$ isopropyl alcohol wipe. Probe head contamination was assessed by periodic swab sampling and obtaining cultures for bacteria and herpes simplex virus. Samples of the sonographic gel also were tested for bacterial contamination at approximately weekly intervals.

A total of 217 condoms were used, 3 of which broke and were discarded while being applied to the probe. During visual inspection, 2 of the 214 condoms used $(0.9 \%)$ were found to have perforations. None of the other 212 condoms leaked upon being filled with water; none of the 204 condoms tested with hydrogen peroxide showed bubbles. Only 1 of the 46 probe swab samples was positive for bacteria (Acinetobacter species); none of the cultures of the 26 probe swab samples grew viruses nor were any of the $25 \mathrm{gel}$ samples positive for bacteria.

The authors concluded that condoms used to cover transvaginal probes showed a low rate of perforation. Disinfection of the probe with isopropyl alcohol wipes further reduced the risk of contamination.

FROM: Amis S, Ruddy M, Kibbler CC, Economides DL, Maclean AB. Assessment of condoms as probe covers for transvaginal sonography. $J$ Clin Ultrasound 2000;28:295-298. 